the final charge, in the present writer's experience, which agrees more or less with the author's, is a very quick and terrible rush, ending in the lion standing up with the great fore-limbs widely extended, claws exposed, and mouth open. All happens in a moment, in a cloud of dust if in dry weather, the fearful right or left sideways blow with the huge paw, which does all the damage, coming almost too swiftly for the eye to follow.

The author, who made four expeditions in eastern equatorial regions before being interned for the duration of the War, also recounts his experiences with elephants in Uganda, but his knowledge of the greatest of beasts is not equal to what it is of the lion and the plains fauna, and, more. over, in this section he suffers apparently at the hands of his interpreter, the book being a translation from the Hungarian. His chapters, which are profusely illustrated with his own photographs dealing with most of the bush fauna and the birds, are very good reading. His final chapter contains useful directions on hunting equipment and the treatment of trophies.

The author's main interests throughout have been apparently the capturing and rearing of young animals, at which he seems to have become an expert. The majority of his antelopes were caught by driving the herds into loop nets, hung in eight or ten parallel rows, the young animals being afterwards turned loose in paddocks and fed, if very young, on milk from bottles fitted with rubber suckers. When tame enough, they were allowed out to graze with zebu cows herded in the same paddock and from which they never attempted to stray. In this way he was eventually able to drive a mixed herd of cows, antelopes and other animals, and ostriches down to the Victoria Nyanza or to the coast for shipment.

\section{Life and Mechanism.}

\section{The Sceptical Biologist (Ten Essays). By Joseph}

Needham. Pp. $\mathrm{v}+288$. (London: Chatto and Windus, 1929.) 7s. $6 d$. net.

$\mathrm{F}$ these ten essays, seven deal with different
aspects of a single topic, the character of the biological sciences and their status among the other sciences. Arising out of this question the relations between science and philosophy and other human activities are considered. Dr. Needham writes in a gay and even frivolous manner, but the subjects he deals with are serious and what he has to say is important. He does not claim that his main thesis is new, but he might justly claim that it has never been better stated.

The gist of the matter may be put in a few sentences. "The biologist is not committed to any opinion as to what his animals are in themselves, but he is committed to the opinion that the scientific method is one way of describing them, and that it is best to apply that method in its fullest rigour if it is to be applied at all" (p. 253). "The mechanistic conception of living organisms is necessitated by the fact that science is, above all, a system of measurement. What can be weighed or made measurable is susceptible of scientific treat. ment; elements of experience which cannot be so discussed are left on one side until they can" (p. 136). "The neo-mechanistic position, therefore, at one and the same time asserting the universal dominion of the mechanical sort of explanation over all nature, living and non-living, and admitting the inadequate nature of this sort of explanation as a full account of the world, resembles the old mechanisticism in maintaining the heuristic need for the machine, and differs from it in seeing nothing solely ultimate about the machine. It thus recognises itself as the way the scientific mind goes to work, and not the manner of thinking in philosophy, theology, and art" (p. 204). Everybody, in fact, who works in a laboratory has to be a mechanist while he is at work. Outside he may think what he likes. The mechanistic theory is like army discipline-necessary for the soldier on duty but intolerable otherwise.

While each individual essay can be unreservedly recommended, read together they do not make a good book. They resemble too much having to eat a succession of teas instead of a dinner.

The three other essays in the book are of a biographical character, but are not unconnected with the main theme of the others. One is on a forgotten biological essay by Coleridge; one on de la Mettrie, the author of "Man a Machine"; the third on the seventeenth century trials for witchcraft and Harvey's connexion with them. Unfortunately, it appears that Harvey never divulged his views on witcheraft, but the nature of his evidence at the trials combined with this very reticence seems to leave a presumption that he was sceptical. The essay is a very interesting little historical sketch.

The author displays a disconcertingly wide knowledge of scientific and philosophical literature and has a happy knack of quotation from unexpected sources. For this reason it is specially disappointing to find the bibliography incomplete. A. D. R. 